\title{
RETÓRICA Y SIGNIFICACIÓN DE LAS IMÁGENES NATURALISTAS EN EL SIGLO XVIII
}

\author{
Antonio E. de Pedro
}

\section{RESUMEN}

La presente comunicación pretende significar la utilización de los recursos propios del lenguaje iconográfico en la estructuración y difusión de los elementos retóricos del lenguaje científico, con especial atención a los siglos XVII y XVIII, como momentos históricos destacados en la configuración de la denominada ciencia moderna.

\section{SUMMARY}

This paper intends to signify the utilization of the iconographic resources of the language in the construction and diffusion of the rhetorical elements of the scientific language, with special attention to the XVIIth and XVIIIth Centuries, as historic outstanding times in the configuration of the so called modern science.

En el siglo XVIII, bajo la denominación de lo visible ${ }^{1}$, el análisis clasificatorio desarrollado desde el Renacimiento por la Historia Natural

${ }^{1}$ Véase, en ampliación de estos conceptos el ya clásico, pero siempre sugerente análisis, de Foucault, M. (1991), Las palabras y las cosas, México, Siglo Veintiuno Editores. Así, como el reciente estudio sobre la obra del pensador francés: JALON, M. (1994), $E l$ laboratorio de Foucault. Descifrar y ordenar, Barcelona, Anthropos/CSIC. 


\section{ANTONIO E. DE PEDRO}

alcanzó, bajo la activación de un proceder taxonómico y combinatorio sin precedentes, el nivel pleno del lenguaje. Esta situación configuró un nuevo marco histórico de asociación intertextual entre las palabras y las imágenes que, bajo preceptos de significación retórica, supuso el abandono definitivo de las semejanzas como recurso descifrador de la realidades naturales. El «todo es posible», expresión simbólica del proceder renacentista, quedo diluido en una totalidad cribada en la que las palabras y las imágenes responderían a intenciones propias del discernir: de «lo que se sabe» se pasa a hablar sólo de «lo que se ve». En definitiva, surge entonces, un nuevo concepto de historia aplicado al conocimiento de la Naturaleza:

«Los documentos de esta nueva historia no son palabras, textos o archivos, sino espacios claros en los que las cosas se yuxtaponen: herbarios, colecciones, jardines; el lugar de esta historia es un rectángulo intemporal en el que los seres, despojados de todo comentario, de todo lenguaje circundante, se presentan unos al lado de los otros, con sus superficies visibles, aproximados de acuerdo con sus rasgos comunes $y$, con ello, virtualmente analizados y portadores de un solo nombre» ${ }^{2}$.

Ahora bien, esta acción en el «orden de lo visible», emprendida desde la tradición de la botánica taxonómica, propició el ascenso de una determinada iconografía ${ }^{3}$ que tenía un cometido muy especifico: la de convertirse en un instrumento de visibilidad de los planteamientos sígnicos del nuevo lenguaje científico. En momentos en que la Historia Natural alcanzaba las cotas más altas de su difusión impresa, a través de obras costosamente editadas y plagadas de numerosas ilustraciones, estas imágenes propiciaban un control de los recursos retóricos. Así, la iconografía naturalista alcanzó un nivel de concreción y de tecnificación nunca visto hasta ahora; tanto el dibujo como el grabado de las láminas botánicas y zoológicas adquirieron una condición de especialidad artística que las proyectaba como instrumentos «veraces» para el conocimiento y la difusión científica; alejándose de tradicionales interpretaciones sobre su auxiliar actividad ornamental.

2 Foucault, F. (1991), p. 134.

3 A esta iconografía responderían imágenes como las que se encuentran, por ejemplo, en obras de naturalistas como Tournefort, Linneo, Adanson, Buffon, etc. 


\section{RETÓRICA Y SIGNIFICACIÓN DE LAS IMÁGENES NATURALISTAS EN EL SIGLO XVIII}

Esta situación venía amparada en una práctica artística que había consensuado la identidad científica del objeto con un minucioso tratamiento artístico de su estructura visible 4 . Para la Historia Natural del Dieciocho, las imágenes debían mostrar una precisa y concisa manera de ver, describiendo aquello expresamente imprescindible para la consecución de los fines del método ${ }^{5}$. La figura, como signo más relevante de esta visualidad, se convierte en el protagonista. En su constitución como forma retórica, a la vez que como resultado de lo que se ha observado en la realidad, adquiere una condición jerarquizante en la configuración estructural de las imágenes. Y para ello se remite a un proceder artístico heredado, consecuencia de un proceso de "afinamiento gráfico" que se remonta a los primeros herbarios renacentistas ${ }^{6}$. De este modo, el silueteado o contorno se afirma como elemento prioritario en la construcción de las figuras, mientras el sombreado por claro-oscuro contendrá, como declara el propio Linneo:

«... toda la historia de la planta como sus nombres, sus estructuras, su conjunto exterior, su naturaleza, su uso» ${ }^{7}$.

Las figuras, con sus formas y volumenes, instrumentan la representación de un lenguaje botánico que sistematiza el nombrar en un tipo: en un icon. Formulaciones fundamentales para esta botánica como la de los cuatro valores propuestos por el sueco Carl Linneo: figura, número, situación y proporción, encuentran reafirmación visual en estas imágenes: el lenguaje clasificatorio sistemático es ante todo y sobre todo pura iconicidad. Como afirma el profesor François Jacob:

«No debe así pues, compararse tal planta con tal otra, sino el número de sus estamb̈res, la forma de sus cálices, la situación de sus anteras, la

${ }^{4}$ Sobre la estructura visible como aspecto predominante en el que la Historia Natural ha fijado su atención para el desarrollo de los distintos sistemas clasificatorios, véase: JACOB, F. (1973), La lógica de lo viviente. Una historia de la herencia, Barcelona, Laia.

5 Véase, Linneo, C. (1751), Philosophie Botanique.

6 Véase, ARBER, A. (1986 reedición a cargo de Stearn W. T), Herbals Their origin and evolution. A chapter in the history of botany. Cambridge, University Press.

${ }^{7}$ LinNeO, C. [(1751), pp. 328-329]. 


\section{ANTONIO E. DE PEDRO}

proporción de sus estambres y de sus pistilos. A fin de cuentas, cualquier planta puede representarse como una reunión de elementos de número y proporción determinados (...)»8.

La botánica, como ciencia del nombrar lo natural, es viable como combinatoria de posibilidades casi ilimitadas, rastreables y confirmables en la lectura de los icones.

A mi modo de ver, de esta situación se pueden extraer dos consecuencias relevantes en relación con la significación teórica de una iconografía con estas características.

La primera se refiere a la confirmación del desplazamiento de la «opción paisajista» como instrumento de visualidad científica. Si a lo largo de la tradición iconográfica botánica esta opción nunca encontró un reconocimiento como "reflejo» de "la clasificatoria», en el siglo XVIII, tras el triunfo de la sistemática, este desinterés obtuvo mayor reforzamiento?.

La naturaleza que observa y describe la botánica sistemática del XVIII, es una naturzaleza atomizada en figuras (icones) que constituyen una determinada manera de apropiación de las condiciones empiricistas en las que ésta se muestra. La idea paisajista de "variedad diseminada» no tiene cavida en una teorización como la anterior, en la que la naturaleza se reduce a géneros, ordenes y clases (Linneo). Pero tampoco en la combinatoria de individuos que configuran el "todo universal» preconizado por Adanson; ni en la más radical individualidad de la propuesta de Buffon. En todas ellas subyace una actitud aislacionista que permite reconocer la realidad natural en tipos. En este sentido, la representación en tipos o icones es una actitud apriorística de acercamiento

8 JACOB, F., op. cit., p. 56.

9 Al final de este siglo, en los albores de la ciencia naturalista romántica, una nueva noción de paisajismo al servicio de la Historia Natural hizo su aparición. Sin duda, fue Alexander von Humboldt quien impulsó la idea de un "paisajismo de las taxonomías». La sustitución del icón por el cuadro en el que quedaran representadas unas determinadas especies como definidoras de una "geografía de las plantas» (de una determinada comar$\mathrm{ca}$, una región), parecía una realidad científicamente útil. (Para un estudio comparativo entre la tradición del icón y este "paisajismo humboltiano», véase: DE PEDRo, A. E., "Las imágenes de los hechos naturales del icón a los cuadros de la naturaleza», en: DíEz TORre, A. R y otros (coordinadores) (1995), De la Ciencia Ilustrada a la Ciencia Romántica. Aranjuez (Madrid), Editorial Doce Calles, pp. 345-356). 
del naturalista a esa realidad natural más que la consecuencia de la aplicación de un método de observación.

La segunda de las consecuencias a la que me interesa referirme es el hecho de la conceptualización del icón como un doble natural. Las figuras esbeltas y preciosistas de las láminas botánicas, encuadradas en un marco de metafórica atemporalidad como emblema de su condición fijista, aspiran a ser un otro. Pero no ese otro réplica o duplicidad imposible del objeto natural, sino otro en su condición de lenguaje: de lenguaje científico de veracidad. De una veracidad a la que la presencia de este doble nos remite en una ampliación del precepto mimético: «esto es aquello».

¿Cuál es entonces ese "aquello» que es proclive a su suplantación por el doble: el de la reproductividad de las condiciones de la apariencia sensible del objeto o, por el contrario, el del plano retórico de la acción significa del lenguaje como "traducción» de lo viviente? La respuesta parece evidente a razón de lo expuesto: el plano retórico de la acción sígnica.

En la época barroca de la ciencia naturalista (siglo XVII), en el «juego de las representaciones» que la caracteriza, el artificio adquirió la condición de vía real de conocimiento: las cosas del mundo había que mirarlas al reves para encontrar su verdadera significación. Esta apreciación, lejos de ignorarse o rechazarse, se convirtió en un referente residual para la iconografía naturalista del Dieciocho. Así, el icón, en su condición de doble, es el artificio por excelencia de los métodos de clasificación empleados por Tournefort o Linneo. En él descansa la naturalización del lenguaje con el que identificar lo observado, la fragmentación del objeto y su articulación; en definitiva, su constitución como una «estructura viviente». De esta manera, la naturaleza es, tan sólo, un «todo sensitivo» del que naturalista extrae (recolecta) aquella información necesaria para la configuración del doble: la aparición de un nuevo tipo será producto de una comparación entre los datos obtenidos en la recolección y la realidad iconográfica del icón; a mayor diferencia, mayor posibilidad de considerar un nuevo tipo; a menos diferencia, entonces más posibilidades de identificar una variante o un especímen de una clase.

En resumen, estamos frente a una iconografía que no admite una simplista clasificación como «instrumento auxiliar». Su involucración en el proceso científico de la Historia Natural reclama una atención a modo de texto, que entra en asociaciones particulares, en cada caso, con los textos escritos. Una iconografía del "puro nombrar" científico que reconoce en sus imágenes el conocimiento de los individuos en sus universa- 
les diferencias: las plantas son lo que son como productos de un lenguaje científico, en la medida que los medios del lenguaje utilizados, así lo revelen. No es cierto que la artificialidad se haya apoderado del «lenguaje naturalista», es que en ella descansa su grandeza, los límites de su proceder científico: el lenguaje es artificial por necesidad representativa en la confección de sus discursos, tanto escritos como icónicos. Y allí, en la realidad creada por la aventura taxonómica, se refleja, clara y de manera verosímil, el orden oculto de la Naturaleza. 
RETÓRICA Y SIGNIFICACIÓN DE LAS IMÁGENES NATURALISTAS EN EL SIGLO XVIII

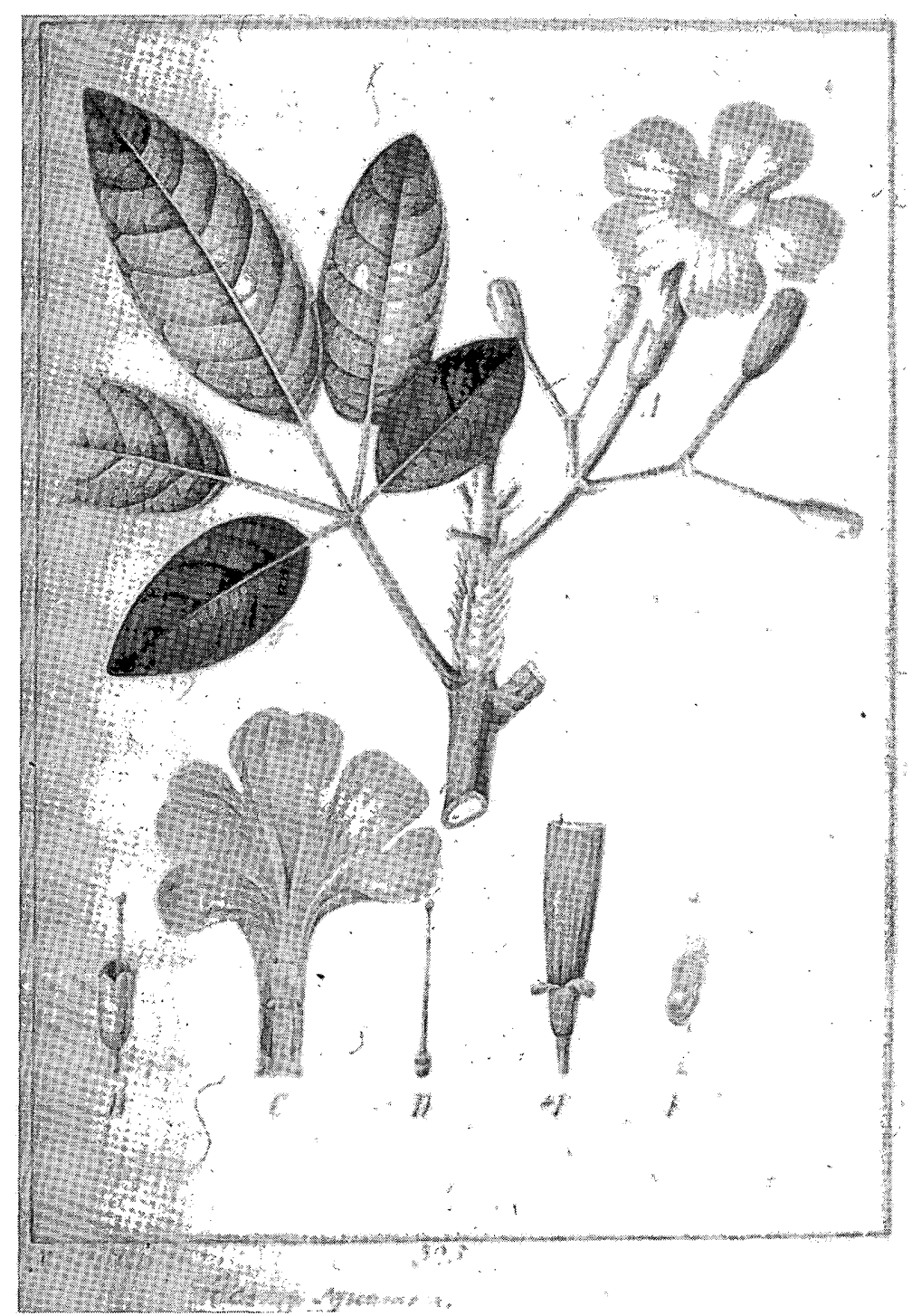

Figura 1

Tecoma squamosa. Javier Cortés, dibujo final para el grabado. Expedición Botánica al Virreinato del Perú (1777-1788) (Real Jardín Botánico dē Madrid). 


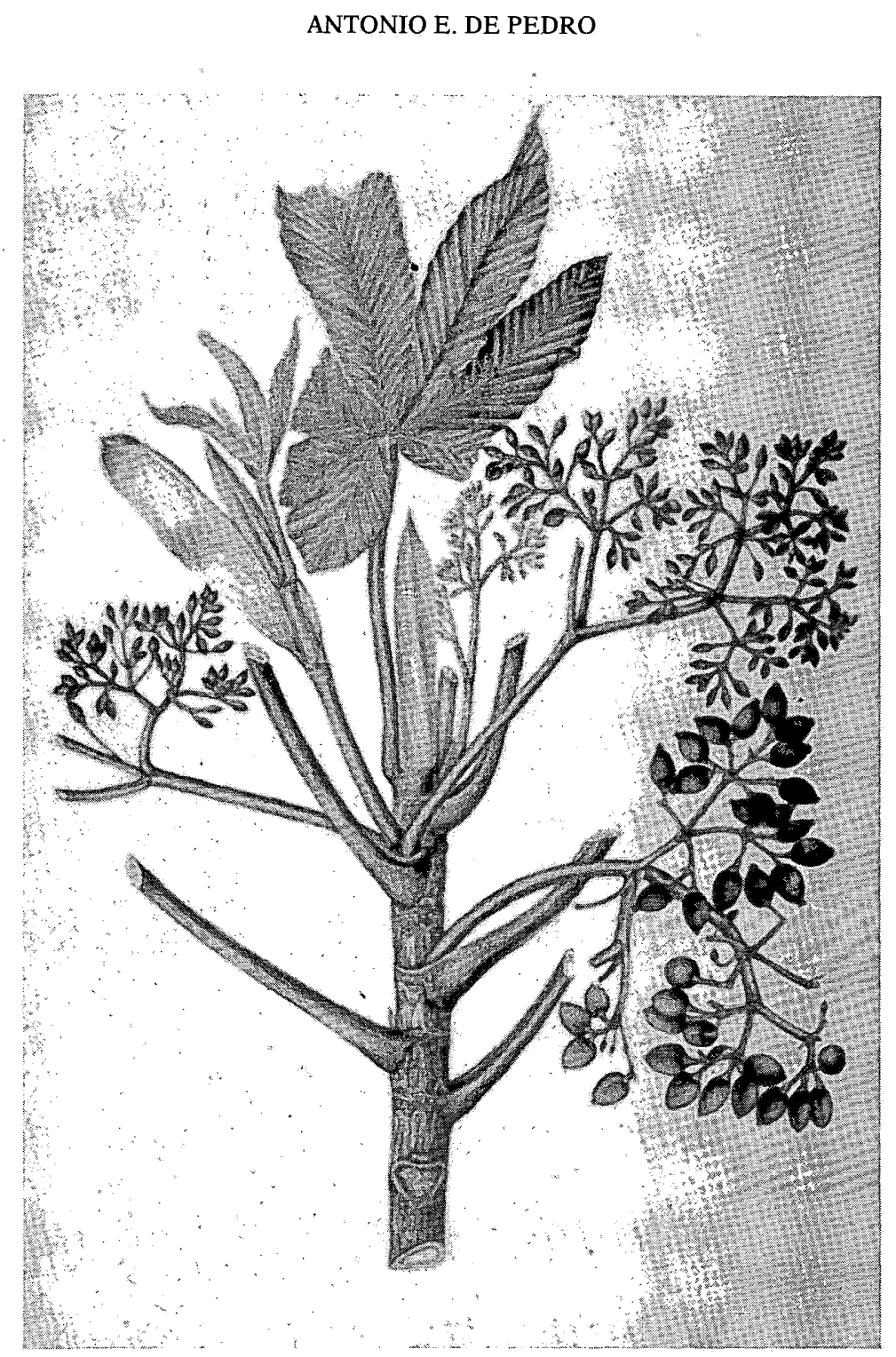

Figura 2

Pourouma guianensis. Dibujo preparatorio.

Expedición Botánica del Nuevo Reino de Granada (1783-1808).

(Colección Mutis, Real Jardín Botánico de Madrid). 